\title{
Passing Off yang Dilakukan Oleh Pihak yang Beritikad Tidak Baik Melalui Pemakaian Nama Perseroan Terbatas
}

\author{
Kimham Pentakosta (a), Elly Hernawati (b) \\ (a) Universitas Surabaya, Kimham@ sajogolaw.com \\ (b) Universitas Surabaya, Elly@ staff.ubaya.ac.id
}

Halaman | 100

\begin{abstract}
This paper focuses on the similarity of functions between Trademarks and Limited Liability Company Name, namely quality assurance function, which enables both to provide a guarantee on the reputation of goods and/or services offered to the consumer. Such similarity of functions between those two different legal terminology opens a loophole for any party, based on bad faith, to conduct passing off towards a registered trademarks owned by another party through the use of a limited liability company name. This paper examine and criticize the laws and regulations relating to the two terminology above, inter alia the Law Number 20 of 2016 regarding Trademarks and Geographical Indications and the Government Regulation Number 43 of 2011 regarding Procedures for Filing and Use of Limited Liability Company Name. This paper concludes that the government of the Republic of Indonesia must immediately amend the regulation on the requirements for submitting the name of a limited liability company, by requiring the Directorate General of General Legal Administration to reject the name of a limited liability company that uses a name that has been registered as a brand by another party.
\end{abstract}

Keywords: Trademarks; Limited Liability Company Name; Passing Off.

\begin{abstract}
Abstrak
Tulisan ini berfokus pada adanya persamaan fungsi antara Merek dan Nama Perseroan Terbatas, yaitu fungsi penjaminan reputasi, yang memungkinkan keduanya untuk memberikan jaminan pada reputasi suatu barang dan/atau jasa yang ditawarkan kepada masyarakat konsumen. Persamaan fungsi antara dua terminologi hukum yang berbeda tersebut membuka celah bagi pihak mana pun, berdasarkan itikad tidak baik, untuk melakukan Passing Off terhadap merek terdaftar yang dimiliki oleh pihak lain melalui penggunaan nama Perseroan Terbatas. Tulisan ini mengkaji dan menganalisa peraturan perundang-undangan yang berkaitan dengan dua terminologi di atas, antara lain Undang-Undang Nomor 20 Tahun 2016 tentang Merek dan Indikasi Geografis serta Peraturan Pemerintah Nomor 43 Tahun 2011 tentang Tata Cara Pengajuan dan Penggunaan Nama Perseroan Terbatas. Tulisan ini berkesimpulan bahwa pemerintah Negara Republik Indonesia perlu melakukan perubahan-perubahan terhadap pengaturan mengenai persyaratan pengajuan nama Perseroan Terbatas, dengan cara mewajibkan Direktorat Jenderal Administrasi Hukum Umum untuk menolak nama Perseroan Terbatas yang menggunakan nama yang telah didaftarkan sebagai merek oleh pihak lain.

Kata Kunci: Merek; Nama Perseroan Terbatas; Passing Off.
\end{abstract}

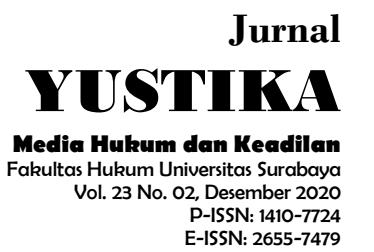


Jurnal Yustika

Vol. 23 No. 02, Des 2020

Halaman | 101

Passing Off yang

Dilakukan oleh

Pihak yang

Beritikad Tidak

Baik Melalui

Pemakaian Nama

Perseroan Terbatas

Kimham Pentakosta

Elly Hernawati

\section{Pendahuluan}

Merek merupakan identitas suatu produk, baik itu berupa barang dan/atau jasa (Rahmi Jened, 2007). Pada saat seorang pelaku usaha berhasil memiliki suatu merek terdaftar, maka pelaku usaha yang bersangkutan akan menerima berbagai macam fungsi dari pendaftaran merek tersebut, antara lain adalah fungsi Penjamin Reputasi atau Quality Assurance (Elmer William Hanak, 1974). Pada saat masyarakat konsumen melihat merek suatu barang dan/atau jasa tertentu, secara otomatis masyarakat konsumen juga dapat mengetahui standar kualitas, asalusul maupun reputasi merek yang bersangkutan.

Pada peraturan perundang-undangan yang berlaku di Indonesia, selain merek, terdapat suatu pengaturan lain yang erat kaitannya fungsi Quality Assurance, yaitu pengaturan mengenai prosedur pengajuan nama Perseroan Terbatas. Menurut Rahmi Jened (2007), persamaan dan perbedaan mengenai keduanya terkadang membingungkan masyarakat. Kebingungan tersebut diakibatkan karena nama Perseroan Terbatas ternyata juga memiliki salah satu fungsi yang sama dengan Merek, yaitu Fungsi Quality Assurance, artinya, pada saat masyarakat konsumen melihat suatu nama Perseroan Terbatas dalam suatu produk barang dan/atau jasa, masyarakat konsumen juga dapat mengasosiakan standar kualitas, asal-usul maupun reputasi tertentu pada produk yang bersangkutan.

Quality Assurance Function atau Fungsi jaminan Reputasi merupakan fungsi yang amat penting agar dapat mendukung terciptanya suatu iklim berusaha yang sehat bagi para pelaku usaha, oleh karenanya perlu adanya suatu integrasi dan harmonisasi antara peraturan perundang-undangan baik di bidang Merek maupun di bidang Nama Perseroan Terbatas agar dapat mencegah segala bentuk tindakan-tindakan yang dilakukan yang mengarah pada persaingan usaha tidak sehat dari pelaku usaha lain, antara lain adalah Passing Off. Sebagaimana diketahui, Passing Off masih belum memiliki suatu definisi normatif dalam peraturan perundang-undangaan di Indonesia, akan tetapi beberapa ahli berpendapat bahwa passing Off dapat diartikan sebagai suatu tindakan yang melanggar norma-norma etika dan/atau kesusilaan dalam berbisnis dengan tujuan untuk membonceng reputasi yang telah dibangun dan dimiliki oleh pelaku usaha lain (Muhammad Djumhana \& Djubaeda, 2003). Berdasarkan hal tersebut di atas, dengan kata lain Passing Off dapat diartikan sebagai suatu pemboncengan reputasi.

Melihat adanya persamaan fungsi dan kemungkinan terjadinya Passing Off antara merek dan nama perseroan terbatas, maka menarik apabila dilakukan kajian terkait dengan peraturan perundang-undangan yang mengatur mengenai prosedur permohonan pendaftaran merek dan prosedur pengajuan nama Perseroan Terbatas, yaitu Undang-Undang Nomor 20 tahun 2016 tentang Merek dan Indikasi Geografis yang telah dirubah dengan Undang Undang Nomor 11 tahun 2020 tentang Cipta Kerja (selanjutnya disebut UU Merek) dan Peraturan Pemerintah Nomor 43 tahun 2011 tentang Tata Cara Pengajuan dan Pemakaian Nama Perseroan Terbatas (selanjutnya disebut PP Nomor 43 Tahun 2011).

Mengacu pada uraian-uraian sebelumnya, maka rumusan masalah yang ditemukan oleh Penulis adalah:

1. Apakah Passing Off dapat dilakukan melalui pemakaian nama Perseroan Terbatas?

2. Apakah pemilik merek terdaftar mendapatkan perlindungan hukum atas Passing Off yang dilakukan melalui pemakaian nama Perseroan Terbatas milik pihak lain? 


\section{Metode Penelitian}

Penelitian ini menggunakan metode yuridis normatif. Penelitian dilakukan dengan cara menganalisa kajian bahan-bahan kepustakaan atau data sekunder yang mencakup bahan-bahan hukum primer, bahan-bahan hukum sekunder dan bahan-bahan hukum tersier, baik berupa literatur, dokumen-dokumen maupun peraturan perundang-undangan yang berlaku.

\section{Hasil Penelitian dan Pembahasan}

\subsection{Passing Off suatu Merek Terdaftar Melalui Pemakaian Nama Perseroan Terbatas}

Tanpa adanya suatu definisi normatif berdasarkan peraturan perundang-undangan, maka dalam memberikan definisi pada passing off harus merujuk pada pendapat para ahli yang terkait, dalam hal ini Rosoque Reynolds dan Natalie Stoianoff berpendapat bahwa suatu tindakan dapat dikategorikan suatu Passing off apabila tindakan tersebut telah memenuhi 3 (tiga) unsur penting, yaitu unsur reputasi, unsur pengelabuhan dan unsur kerugian. Pemenuhan ketiga unsur tersebut di atas disebut dengan teori Classical Trinity (Julius Rizaldi, 2009). Terkait dengan hal tersebut di atas, untuk menjawab Rumusan Masalah pertama, perlu dikaji bahwa penggunaan nama merek terdaftar sebagai nama perseroan terbatas telah memenuhi 3 (tiga) unsur Classical Trinity.

\subsubsection{Unsur Reputasi (goodwill) Pada Pemakaian Nama Perseroan Terbatas Yang Menggunakan Nama Merek Milik Orang Lain.}

Reputasi atau goodwill dapat dikatakan sebagai salah satu bentuk pengakuan (Recognition) dari masyarakat konsumen terhadap tingkat kualitas suatu produk tertentu. Suatu reputasi terbentuk dari intensitas penyebaran informasi dari satu pengguna produk ke pengguna produk lainnya. Menurut Loureiro, apabila sebuah perusahaan dapat meningkatkan dan mempertahankan reputasi yang dimiliki olehnya, maka reputasi yang dimiliki tersebut akan menjadi poros penggerak bagi terciptanya kecintaan akan suatu produk (brand attachment) dan loyalitas pengguna (brand loyalty) pada masyarakat konsumen (Loureiro, 2017).

Menurut Rahmi Jened (2015), reputasi dari suatu produk tidak secara otomatis diperoleh dari pendaftaran merek, melainkan diperoleh dari hasil usaha pemilik merek dalam menjaga kualitas produk dan melakukan pemasaran (promosi) yang baik, sehingga produk miliknya dapat diterima dan dikenal oleh masyarakat konsumen secara luas. Hal tersebut di atas menunjukan bahwa reputasi bukan merupakan suatu hal yang mudah untuk dimiliki, beberapa contoh menunjukkan bahwa reputasi dari suatu produk membutuhkan waktu bertahun-tahun bahkan berpuluh-puluh tahun dalam membangun citra atau image dari merek tersebut.

Secara normatif, hukum telah memberikan suatu terminologi yang sangat erat kaitannya dengan unsur reputasi sebagaimana dijelaskan di atas, yaitu terminologi Merek Terkenal. Berdasarkan Pasal 18 Peraturan Menteri Hukum dan Hak Asasi Manusia (Permenkumham) Nomor 67 Tahun 2016 tentang Merek Terkenal, salah satu persyaratan atau kriteria suatu merek diberikan status Merek Terkenal adalah unsur Reputasi. 
Jurnal Yustika

Vol. 23 No. 02, Des 2020

Halaman | 103

Passing Off yang

Dilakukan oleh

Pihak yang

Beritikad Tidak

Baik Melalui

Pemakaian Nama

Perseroan Terbatas

Kimham Pentakosta

Elly Hernawati
Pengaturan unsur reputasi sebagai salah satu kriteria wajib tersebut menunjukan bahwa merek-merek yang dapat diberikan status Merek Terkenal oleh Kementerian Hukum dan Hak Asasi Manusia (selanjutnya disebut Kemenkumham) adalah merek-merek yang memang memiliki reputasi dan telah dikenal dengan baik oleh masyarakat konsumen. Apabila dikaitkan dengan unsur reputasi (goodwill) pada Passing Off melalui pemakaian nama Perseroan Terbatas, dapat dikatakan bahwa unsur reputasi pada tindakan Passing Off dapat terpenuhi apabila nama merek yang dipakai sebagai nama Perseroan Terbatas tersebut merupakan nama suatu Merek Terkenal.

\subsubsection{Unsur Pengelabuhan (misrepresentation) Pada Pemakaian Nama Perseroan Terbatas Yang Menggunakan Nama Merek Milik Orang Lain.}

Menurut Agung Sujatmiko (2010), pengelabuhan secara sederhana dapat dibuktikan apabila tindakan seseorang tersebut mengakibatkan konsumen beranggapan bahwa suatu produk berupa barang dan/atau jasa tersebut dimiliki oleh seseorang yang lain, bukan milik pemilik aslinya.

Pada penelitian ini, terdapat 3 (tiga) hal untuk membuktikan bahwa telah terjadi Pengelabuhan (misrepresentation) melalui Pemakaian nama Perseroan Terbatas yaitu:

1. Pencantuman nama Perseroan Terbatas yang menggunakan nama merek milik orang lain dalam kemasan produk;

2. Penggunaan kata lain pada Nama Perseroan Terbatas yang berhubungan dengan jenis barang dan/atau jasa;

3. Penggunaan akronim atau singkatan Nama Perseroan Terbatas yang sama dengan nama Merek Terdaftar milik orang lain.

Ad. 1. Pencantuman nama Perseroan Terbatas yang menggunakan nama merek milik orang lain dalam kemasan produk.

Pelaku usaha wajib mencantumkan nama dari Perseroan Terbatas pada jenis produk berupa barang yang diperjualbelikan. Hal ini terdapat dalam berbagai peraturan perundang-undangan, antara lain Undang-Undang Nomor 8 Tahun 1999 tentang Perlindungan Konsumen (selanjutnya disebut UU Perlindungan Konsumen) dan Undang-Undang Nomor 18 Tahun 2012 tentang Pangan (selanjutnya disebut UU Pangan).

Berdasarkan peraturan-peraturan di atas, pencantuman nama Perseroan Terbatas yang melakukan produksi barang wajib dilakukan secara hukum, akan tetapi apabila nama Perseroan Terbatas tersebut ternyata menggunakan nama merek terdaftar milik pihak lain, maka tidak menutup kemungkinan masyarakat konsumen akan mengasosiasikan barang tersebut dengan merek terdaftar yang bersangkutan. 
Gambar 1. Ilustrasi Kemasan Produk AISHA

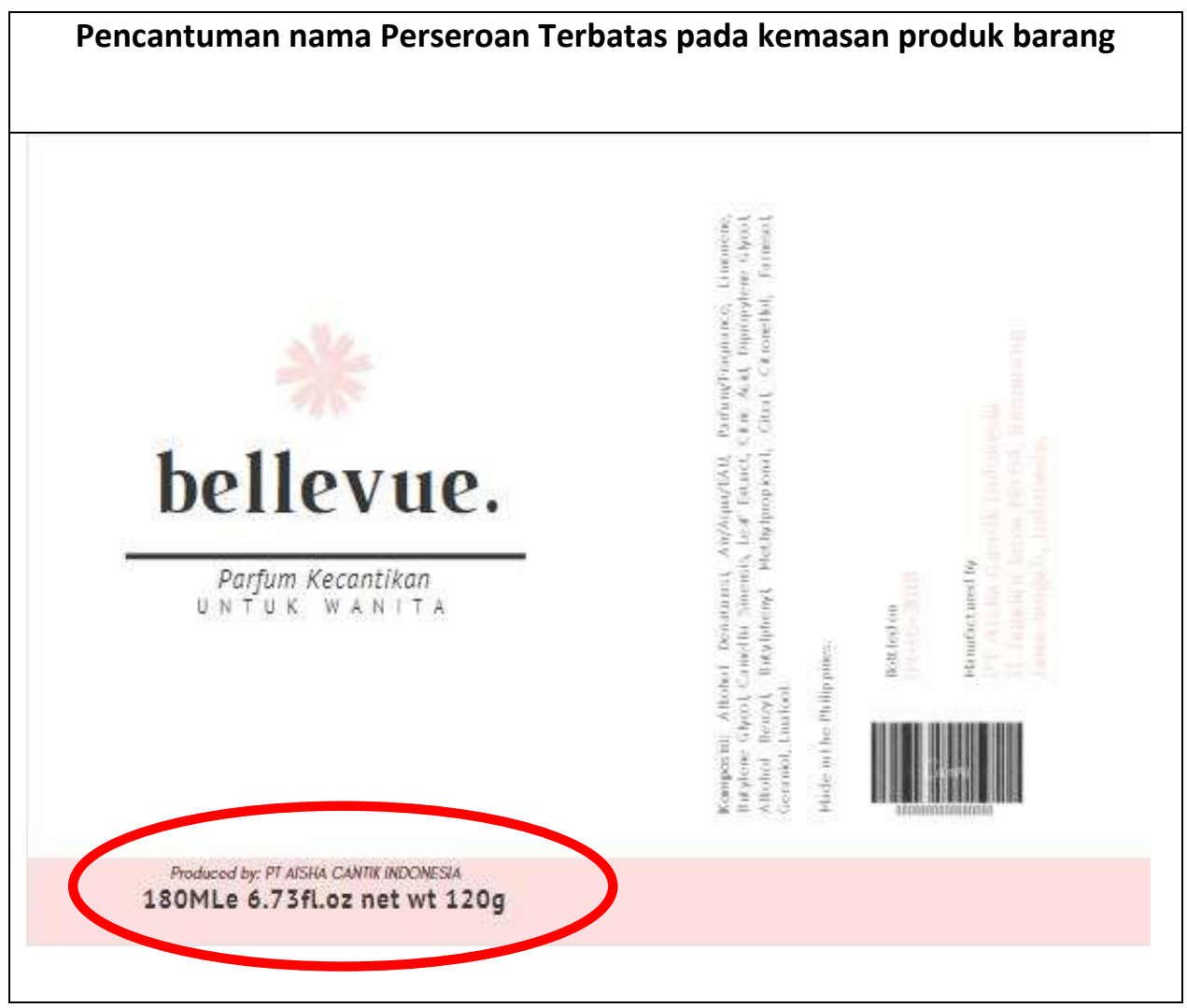

Jurnal Yustika Vol. 23 No. 02, Des 2020

Halaman | 104

Passing Off yang

Dilakukan oleh

Pihak yang

Beritikad Tidak Baik

Melalui Pemakaian

Nama Perseroan

Terbatas

Kimham Pentakosta Elly Hernawati

Pengasosiasian tersebut di atas dilakukan oleh karena adanya unsur persamaan antara suatu nama dengan nama yang lain, dalam hal ini antara nama Perseroan Terbatas yang muncul pada kemasan dengan suatu merek yang telah dikenal dan diterima oleh masyarakat konsumen. Berdasarkan UU Merek, unsur persamaan tersebut dikenal dengan terminologi "persamaan pada pokoknya". Apabila mengacu pada Penjelasan Pasal 21 UU Merek, yang dimaksud dengan "persamaan pada pokoknya" adalah kemiripan yang diakibatkan oleh unsur-unsur dominan yang menimbulkan kesan persamaan bentuk, cara penempatan, cara penulisan atau kombinasi antara unsur, maupun persamaan bunyi ucapan.

Rahmi Jened, dalam bukunya yang berjudul "Hukum Merek (Trademark Law) Dalam Era Global \& Integrasi Ekonomi" (2015), mengutip pendapat dari Robert Braunies yang mengemukakan standar yang sangat luas dari "persamaan pada pokoknya" yaitu: (a) mark need not be identical (tanda tidak harus memiliki persamaan yang identik); (b) goods need not be competing (barang atau jasa tidak perlu bersaing); dan (c) need not confuse all consumers (tidak harus membingungkan semua konsumen).

Kebingungan dalam masyarakat konsumen mengenai sumber maupun kualitas suatu produk ("likelihood of confusion" dan "likelihood of association") timbul karena adanya "persamaan pada pokoknya" antara suatu merek dengan suatu nama Perseroan Terbatas. Hal ini disebabkan pemegang merek memiliki hak eksklusif untuk menggunakan nama merek yang telah didaftarkan pada produk miliknya, akan tetapi di sisi yang lain, tedapat 
Jurnal Yustika

Vol. 23 No. 02, Des 2020

Halaman | 105

Passing Off yang

Dilakukan oleh

Pihak yang

Beritikad Tidak

Baik Melalui

Pemakaian Nama

Perseroan Terbatas

Kimham Pentakosta

Elly Hernawati pihak-pihak yang mempunyai hak ekskusif untuk menggunakan nama Perseroan Terbatas dan sekaligus juga telah didaftarkan.

Ad. 2. Penggunaan kata lain pada Nama Perseroan Terbatas yang berhubungan dengan jenis barang dan/atau jasa;

Suatu Nama Perseroan Terbatas dapat terdiri dari lebih dari 1 (satu) kata. Walaupun PP Nomor 43 tahun 2011 tidak secara spesifik mengatur berapa jumlah kata yang dapat dijadikan suatu nama Perseroan Terbatas, namun secara praktik sistem Administrasi Hukum Umum (AHU) pada Kemenkumham mempersyaratkan nama Perseroan Terbatas wajib terdiri dari 3 (tiga) kata atau lebih (J. Satrio, 2020).

Pengelabuhan (misrepresentation) melalui nama Perseroan Terbatas dapat dibuktikan dengan adanya pemilihan kata atau nama lain, selain nama Merek Terdaftar yang bersangkutan, yang berhubungan dengan karakteristik barang dan/atau jasa Merek Terdaftar yang bersangkutan. Sebagai contoh ilustrasi, seorang pelaku usaha memiliki Merek Terdaftar "Aisha" yang bergerak di bidang jasa klinik kecantikan, suatu saat menemukan suatu Perseroan Terbatas milik orang lain yang menggunakan nama "PT Aisha Cantik Indonesia", pemilihan kata "Cantik" pada nama Perseroan Terbatas tersebut berhubungan dengan karakteristik Merek Terdaftar "Aisha" yang bergerak pada jasa klinik kecantikan, oleh karenanya pemilihan kata "Cantik" dapat dianggap suatu bentuk Pengelabuhan (misrepresentation) yang dilakukan oleh pihak yang memiliki itikad tidak baik. Dipilihnya kata "Cantik" untuk dipakai bersama-sama dengan kata "Aisha" pada suatu nama Perseroan Terbatas akan mengakibatkan masyarakat konsumen beranggapan bahwa suatu produk berupa barang dan/atau jasa tersebut dimiliki atau terasosiasi pada Merek Terdaftar "Aisha", yang memang bergerak pada bidang jasa klinik kecantikan.

Ad. 3. Penggunaan akronim atau singkatan Nama Perseroan Terbatas yang sama dengan nama Merek Terdaftar milik orang lain.

Suatu Nama Perseroan Terbatas dapat dimohonkan dengan menggunakan suatu akronim atau singkatan nama, sebagaimana diatur pada ketentuan Pasal 2 ayat (2) PP Nomor 43 Tahun 2011. Lebih lanjut Pasal 5 ayat (2) dan (3) PP Nomor 43 Tahun 2011 pada intinya mengatur bahwa suatu singkatan Perseroan Terbatas dapat terdiri atas huruf depan Nama Perseroan Terbatas atau singkatan yang merupakan akronim dari Nama Perseroan Terbatas. Penjelasan Pasal 5 ayat (2) dan (3) PP Nomor 43 Tahun 2011 tersebut memberikan beberapa contoh sebagai berikut: PT SAHABAT FINANSIAL SEJAHTERA disingkat dengan PT SAFIRA, PT TABUNGAN ASURANSI PEGAWAI NEGERI disingkat dengan PT TASPEN, PT ASURANSI KESEHATAN disingkat dengan PT ASKES, atau PT PELABUHAN INDONESIA disingkat dengan PT PELINDO.

Menurut J. Satrio (2020), kata "beserta" pada Pasal 3 ayat (2) PP Nomor 43 Tahun 2011 tersebut berarti harus ada nama yang memenuhi syarat peraturan perundangundangan, baru boleh disertai dengan suatu singkatan.

Hal tersebut di atas menarik apabila dikaitkan dengan unsur pengelabuhan yang dapat dilakukan melalui pemakaian nama Perseroan Terbatas. Pihak yang memiliki itikad tidak baik dapat memanfaatkan pemberian singkatan atau akronim sebagaimana diatur pada peraturan tersebut di atas untuk melakukan suatu pengelabuhan (misrepresentation) pada suatu Merek Terdaftar milik pihak lain. 
Pihak yang memiliki itikad tidak baik dapat memakai suatu akronim atau singkatan nama Perseroan Terbatas yang merupakan nama suatu Merek Terdaftar sebagaimana Penjelasan Pasal 5 ayat (2) dan (3) PP Nomor 43 Tahun 2011, misalnya : SAFIRA sebagai akronim dari nama PT SAHABAT FINANSIAL SEJAHTERA, akan tetapi berdasarkan database Merek Terdaftar yang dapat diakses melalui https://pdkiindonesia.dgip.go.id/, nama "SAFIRA" sendiri ternyata sudah terdaftar sebagai Merek dengan nomor pendaftaran IDM000623309 atas nama Anwar Ja'far Baraja di Kelas 36 (tiga puluh enam) dengan spesifikasi jasa penilaian tanah dan bangunan.

Mengenai hal tersebut di atas menunjukan bahwa Pihak yang memiliki itikad tidak baik dapat menggunakan suatu nama Merek Terdaftar milik pihak lain sebagai akronim atau singkatan nama Perseroan Terbatas miliknya, sehingga terjadi pengelabuhan (misrepresentation) dan menyebabkan masyarakat konsumen mengasosiasikan akronim nama Perseroan Terbatas yang bersangkutan dengan suatu nama Merek Terdaftar yang sama.

\subsubsection{Unsur Kerugian (damages) Pada Pemakaian Nama Perseroan Terbatas Yang Menggunakan Nama Merek Milik Orang Lain.}

Unsur ketiga dan terakhir yang perlu dibuktikan adalah adanya kerugian yang dapat diderita oleh pemilik merek terdaftar. Menurut Bently (2009), kerugian tersebut harus dilihat sebagai suatu akibat dari Pengelabuhan (misrepresentation) yang dilakukan oleh pihak yang tidak beritikad baik.

Pada penelitian ini, Setidaknya terdapat 3 (tiga) analisa untuk membuktikan bahwa dapat terjadi Kerugian (damages) yang diderita oleh pemilik merek terdaftar melalui Pemakaian nama Perseroan Terbatas, antara lain:

1. Kerugian materiil yang diderita oleh pemilik merek terdaftar;

2. Kerugian immateriil yang diderita oleh pemilik merek terdaftar; dan

3. Kerugian yang timbul akibat hak-hak yang diberikan oleh hukum kepada pemilik nama perseroan terbatas yang menggunakan nama merek terdaftar.

Ad. 1. Kerugian materiil yang diderita oleh pemilik merek terdaftar;

Pemilik Merek Terdaftar akan mengalami kerugian dalam bentuk berkurangnya laba/keuntungan atas penjualan produk karena adanya penurunan penjualan produk yang merupakan konsekuensi logis dari pemakaian suatu nama Perseroan Terbatas milik pihak lain yang menggunakan nama merek terdaftar miliknya.

Pengelabuhan yang dilakukan melalui pemakaian nama Perseroan Terbatas juga dapat mengakibatkan pemilik merek terdaftar menderita kerugian dalam bentuk kehilangan potential profit atau keuntungan yang seharusnya didapatkan.

Berdasarkan UU Merek, pemilik merek terdaftar mempunyai hak eksklusif menggunakan nama merek yang telah didaftarkan. Pihak selain pemilik merek apabila hendak menggunakan merek yang bersangkutan, maka wajib mendapatkan izin terlebih dahulu dari pemilik merek melalui pemberian lisensi. Pasal 42 UU Merek secara eksplisit mengatur mengenai hak pemilik merek terdaftar untuk memberikan lisensi kepada pihak 
Jurnal Yustika

Vol. 23 No. 02, Des 2020

Halaman | 107

Passing Off yang

Dilakukan oleh

Pihak yang

Beritikad Tidak

Baik Melalui

Pemakaian Nama

Perseroan Terbatas

Kimham Pentakosta

Elly Hernawati lain untuk menggunakan nama merek miliknya. Pengaturan tersebut di atas berarti penggunaan secara sah atas suatu nama merek terdaftar oleh pihak lain hanya dapat didasari oleh perjanjian lisensi (Agung Sujatmiko, 2010).

Pada perjanjian lisensi, dapat disepakati oleh para bahwa penerima lisensi wajib membayar royalti atau biaya lisensi kepada pemilik merek terdaftar sebagai pemberi lisensi. Hal tersebut tidak perlu dilakukan apabila pihak yang beritikad tidak baik dapat memakai nama merek terdaftar sebagai nama Perseroan Terbatas, akibatnya, pemilik merek terdaftar juga menderita kerugian dalam bentuk tidak didapatkannya pembayaran royalti atau biaya lisensi atas penggunaan nama merek terdaftar miliknya.

Ad. 2. Kerugian immateriil yang diderita oleh pemilik merek terdaftar;

Kerugian immateriil dapat terjadi apabila pemakaian nama Perseroan Terbatas yang menggunakan nama merek terdaftar ternyata membawa suatu dampak negatif terhadap reputasi yang dimiliki oleh pemilik merek terdaftar yang bersangkutan (Bently, 2009). Sebagaimana telah dijelaskan pada bagian sebelumnya, baik nama Perseroan Terbatas maupun nama merek terdaftar sama-sama memiliki fungsi jaminan kualitas atau Quality Assurance Function, artinya apabila kualitas dari barang/jasa yang dipasarkan oleh suatu Perseroan Terbatas yang memakai nama suatu merek terdaftar ternyata tidak diterima dengan baik oleh masyarakat konsumen, hal tersebut akan berpengaruh terhadap reputasi merek terdaftar yang bersangkutan.

Ad. 3. Kerugian yang timbul akibat hak-hak yang diberikan oleh hukum kepada pemilik nama perseroan terbatas yang menggunakan nama merek terdaftar.

Pada beberapa permohonan pendaftaran merek sebagaimana dapat ditelusuri dalam situs https:/ / pdki-indonesia.dgip.go.id/, Pemohon dapat memasukan keterangan atau dalil bahwa nama merek yang dimohonkan itu juga merupakan bagian nama dari Pemohon. Sebagai contoh: Permohonan Pendaftaran Merek "HELMIGS" dengan nomor pendaftaran IDM000567724 didaftarkan oleh PT Helmigs Prima Sejahtera dengan translasi: "Helmigs merupakan nama perusahaan pemohon", atau Permohonan Pendaftaran Merek "CIPUTRA WORLD" dengan nomor pendaftaran IDM000217774 yang didaftarkan oleh PT Ciputra Corpora dengan translasi: "CIPUTRA: Bagian Nama Perusahaan WORLD: Dunia" serta banyak permohonan pendaftaran lainnya.

Contoh-contoh permohonan pendaftaran merek di atas menggambarkan bahwa pendaftaran nama Perseroan Terbatas sebagai nama merek sering dijadikan legitimate interest bagi pemohon agar pemeriksa merek dapat mempertimbangkan untuk mengabulkan permohonan pendaftaran merek yang diajukan.

Hal tersebut di atas apabila dikaitkan dengan Passing off dalam pemakaian nama Perseroan Terbatas sebagaimana telah dijelaskan sebelumnya, maka apabila terdapat seseorang yang tidak mempunyai itikad baik dan berkehendak untuk melakukan Passing 
off terhadap suatu merek, maka orang tersebut dapat, dengan tanpa melawan hukum, mendirikan suatu Perseroan Terbatas dengan menggunakan nama yang mempunyai persamaan pada pokoknya dengan merek tersebut, lalu kemudian mendaftarkan nama

perusahaannya sebagai nama merek. Tentu hal tersebut merupakan suatu kerugian bagi pemilik merek terdaftar yang bersangkutan, karena pihak lain dapat mendaftarkan suatu nama yang sebenarnya telah menjadi hak ekslusif dan dilindungi oleh hukum sebagai merek terdaftar miliknya.

\subsection{Perlindungan Hukum Kepada Pemilik Merek Terdaftar Atas Passing Off Melalui Pemakaian Nama Perseroan Terbatas.}

\subsubsection{Pemakaian Merek Terdaftar sebagai Nama Perseroan Terbatas.}

Pengaturan mengenai pengajuan permohonan pendaftaran merek dan pengajuan

\section{i} nama perseroan terbatas diatur dan dilakukan oleh struktur organisasi pemerintahan yang berbeda. Sebagaimana diatur dalam Peraturan Menteri Hukum dan Hak Asasi Manusia Nomor 29 Tahun 2019 tentang Organisasi dan Tata Kerja Kementerian Hukum dan Hak Asasi Manusia, prosedur pengajuan permohonan pendaftaran hak atas merek berada di bawah kewenangan Direktorat Jenderal Kekayaan Intelektual (selanjutnya disebut DJKI), sedangkan prosedur pengajuan nama Perseroan Terbatas berada di bawah kewenanganan Direktorat Administrasi Hukum Umum (selanjutnya disingkat Direktorat AHU). Pemisahan pengaturan dan kewenangan secara struktur organisasi antara merek dan nama Perseroan Terbatas tersebut dapat mengakibatkan tidak adanya harmonisasi pengaturan, baik di bidang persyaratan pengajuan, proses pemeriksaan, dan pengambilan keputusan.

Sebenarnya telah ada usaha-usaha untuk melakukan harmonisasi mengenai pengaturan di bidang merek dan nama Perseroan Terbatas. Pembuat undang-undang, (dalam hal ini UU Merek), sebenarnya telah melihat adanya relevansi antara merek dengan nama perusahaan, termasuk nama Perseroan Terbatas. Relevansi tersebut secara implisit terlihat pada pengaturan mengenai persyaratan pengajuan permohonan Merek sebagaimana diatur pada Pasal 21 ayat (2) huruf a UU Merek, yang pada intinya menentukan bahwa permohonan pendaftaran merek harus ditolak apabila merek yang diajukan ternyata merupakan atau menyerupai nama badan hukum.

Terkait dengan frase "nama badan hukum" yang terdapat pada ketentuan Pasal 21 ayat (2) huruf a UU Merek di atas, menunjukan bahwa pada saat proses pemeriksaan substantif terhadap setiap permohonan pendaftaran merek harus memperhatikan juga nama badan hukum yang dimiliki oleh orang lain, dengan kata lain pada saat suatu merek diajukan permohonannya, seorang pemeriksa merek diwajibkan oleh peraturan perundang-undangan untuk memeriksa daftar nama badan hukum yang telah ada di Indonesia, termasuk daftar nama Perseroan Terbatas. Sehubungan dengan ini, dapat dikatakan telah terjadi suatu proses pemeriksaan silang atau cross examination antara nama merek yang hendak didaftarkan dengan nama perseroan terbatas yang telah ada di 
Jurnal Yustika

Vol. 23 No. 02, Des 2020

Halaman | 109

Passing Off yang

Dilakukan oleh

Pihak yang

Beritikad Tidak

Baik Melalui

Pemakaian Nama

Perseroan Terbatas

Kimham Pentakosta

Elly Hernawati
Indonesia sebelumnya. Pemeriksaan silang (cross examination) yang dimaksud disini merupakan pemeriksaan yang dilakukan antar lembaga struktural yang berbeda, dalam hal ini antara DJKI dan Direktorat AHU. Sesuai dengan ketentuan Pasal 21 ayat (2) huruf a UU Merek, pada saat ada permohonan pendaftaran suatu merek, DJKI tidak hanya melakukan pemeriksaan terhadap data merek terdaftar yang ada pada DJKI, melainkan juga melakukan pemeriksaan terhadap data perseroan terbatas yang ada pada Direktorat AHU.

Permasalahan terjadi dikarenakan prosedur pemeriksaan silang (cross examination) yang secara tegas disebutkan sebagaimana ditentukan dalam UU Merek, ternyata tidak demikian pengaturan mengenai pengajuan nama Perseroan Terbatas sebagaimana diatur pada PP Nomor 43 Tahun 2011. Tidak ada ketentuan dalam PP Nomor 43 Tahun 2011 yang mengatur bahwa nama Perseroan Terbatas yang sama dengan nama merek terdaftar harus ditolak. Ketentuan pada Pasal 5 ayat (1) huruf b PP Nomor 43 Tahun 2011 hanya mensyaratkan bahwa pemeriksaan nama Perseroan Terbatas yang dimohonkan dilakukan terhadap nama-nama Perseroan Terbatas yang telah ada sebelumnya. Hal ini berarti, pada saat seseorang mengajukan permohonan nama Perseroan Terbatas, Direktorat AHU hanya akan memeriksa nama tersebut tidak dimiliki oleh badan hukum atau perseroan lain sesuai dengan ketentuan Pasal 5 ayat (1) PP Nomor 43 Tahun 2011 dan tidak memeriksa bahwa nama Perseroan Terbatas yang dimohonkan tersebut memiliki persamaan pada pokoknya dengan merek terdaftar atau tidak.

Tidak adanya pemeriksaan silang (cross examination) antara prosedur permohonan nama merek dan prosedur permohonan nama Perseroan Terbatas dapat mengakibatkan banyaknya nama merek terdaftar yang memiliki persamaan pada pokoknya dan/atau keseluruhannya dengan nama suatu Perseroan Terbatas yang telah dimiliki oleh orang lain sebelumnya.

Berdasarkan data yang diolah dari laman resmi Pangkalan Data Kekayaan Intelektual (https://pdki-indonesia.dgip.go.id/) dan Data Perseroan Terbatas (https://ahu.go.id/profil-pt) di Indonesia, berikut terdapat beberapa nama merek terdaftar milik seseorang yang memiliki persamaan pada pokoknya maupun keseluruhannya dengan nama Perseroan Terbatas yang sudah ada di Indonesia: 
Tabel 1. Merek dan Nama Perusahaan

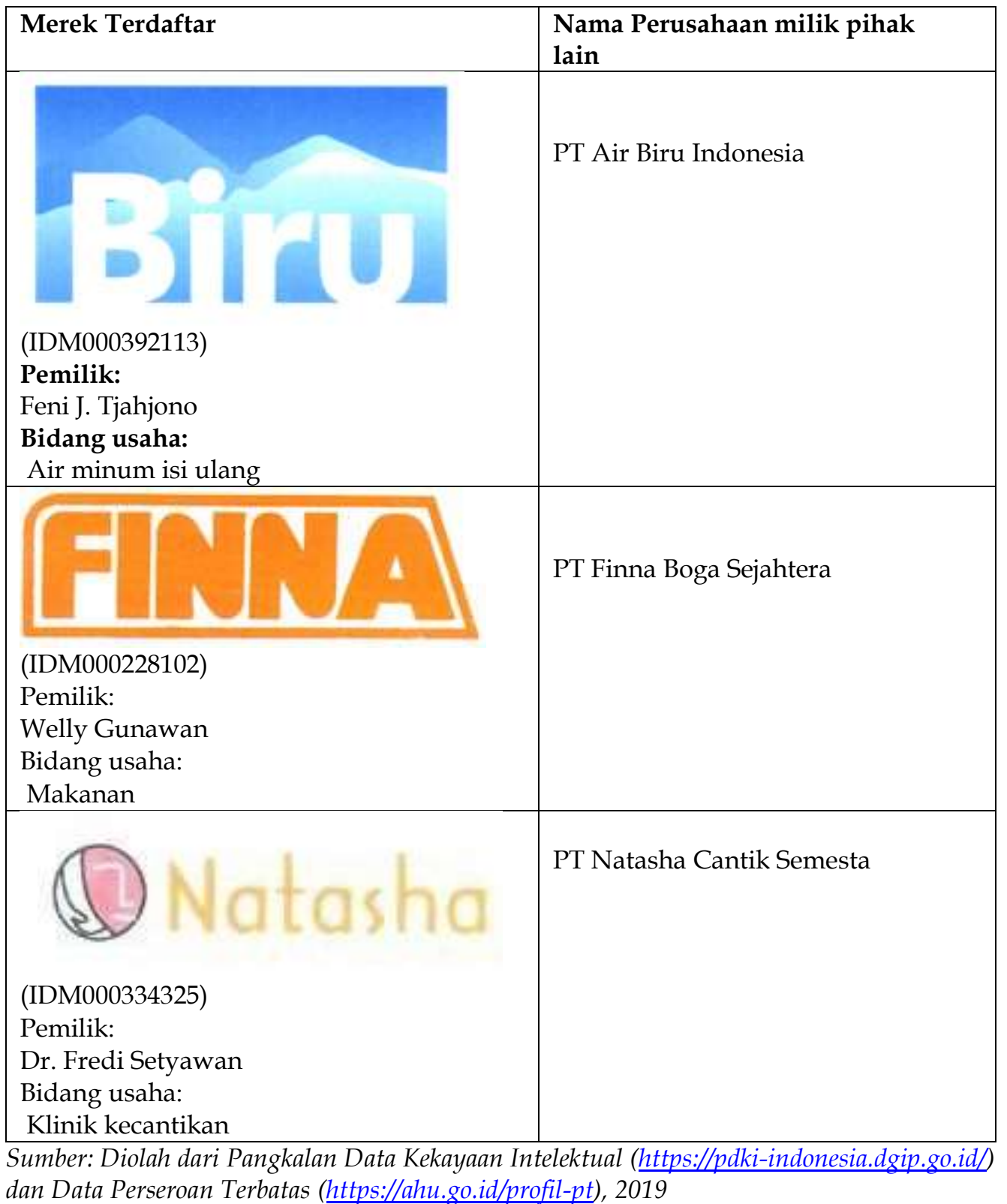
Vol. 23 No. 02, Des 2020

Halaman | 110

Passing Off yang

Dilakukan oleh

Pihak yang

Beritikad Tidak Baik

Melalui Pemakaian

Nama Perseroan

Terbatas

Kimham Pentakosta Elly Hernawati

Berbeda halnya dengan pengaturan mengenai perlindungan hukum terhadap pemilik merek terdaftar di beberapa negara maju telah mendapatkan perhatian, salah satunya ada negara Australia. Tata cara pengajuan dan pemakaian nama perusahaan di negara Australia diatur oleh Australian Securities \& Investment Comitees atau ASIC dan didasarkan pada Business Names Registration Act 2011.

Business Names Registration Act 2011 merupakan undang-undang nasional yang mengatur mengenai pendaftaran nama perusahaan di Australia dan telah diubah (amendment) terakhir kali pada tanggal 1 Juli 2016. Pada bagian-bagian pengaturan Business Names Registration Act 2011, telah terdapat pengaturan yang beririsan langsung 
Jurnal Yustika

Vol. 23 No. 02, Des 2020

Halaman | 111 Passing Off yang Dilakukan oleh Pihak yang Beritikad Tidak Baik Melalui Pemakaian Nama Perseroan Terbatas

Kimham Pentakosta Elly Hernawati dengan undang-undang yang mengatur mengenai pendaftaran merek di Australia, yaitu Trade Marks Act 1995. Hal tersebut di atas menunjukan bahwa di Australia telah menciptakan suatu sistem pengaturan yang terintegrasi antara prosedur pendaftaran merek berdasarkan Trade Marks Act 1995 dan prosedur pendaftaran nama perusahaan berdasarkan Business Names Registration Act 2011.

Perlindungan hukum kepada pemilik merek terdaftar dan menjaga iklim persaingan usaha yang sehat di Australia telah tercermin pada Division 5 - Objects of this Act and consequences of registration yang pada intinya menjelaskan maksud dan tujuan diundangkannya Business Names Registration Act 2011. Division 5 pada intinya menjelaskan bahwa tujuan diadakannya peraturan perundang-undangan ini, yaitu:

1. Menghindari kekeliruan masyarakat dengan memastikan bahwa nama usaha yang identikal atau hampir identikal tidak dapat didaftarkan;

2. Memastikan nama-nama usaha yang tidak diharapkan (sebagai contoh, nama yang mengandung kata-kata yang ofensif) tidak dapat didaftarkan;

3. Memastikan bahwa nama-nama usaha yang harus dilarang karena dapat menyesatkan masyarakat konsumen tidak dapat didaftarkan.

Ketentuan mengenai prosedur pendaftaran nama usaha atau perusahaan dalam Business Names Registration Act 2011 sebenarnya pada prinsipnya sama dengan apa yang diatur pada PP Nomor 43 Tahun 2011, suatu nama usaha atau perusahaan akan dimohonkan dan melewati suatu prosedur pemeriksaan substantif oleh badan atau instansi yang berwenang. Di Australia, suatu nama usaha atau perusahaan harus terlebih dahulu memenuhi syarat-syarat yang ditentukan pada Part 3 - Article 25 Business Names Registration Act 2011, baru kemudian mendapatkan persetujuan dari ASIC. Mekanisme tersebut pada prinsipnya sama dengan persyaratan nama perseroan terbatas sebagaimana diatur pada Pasal 5 PP Nomor 43 Tahun 2011 yang berlaku di Indonesia.

Perbedaan yang mendasar antara keduanya terletak pada mekanisme pembatalan nama perusahaan, berdasarkan Business Names Registration Act 2011, suatu pelanggaran merek merupakan salah satu alasan sah bagi seorang pihak untuk memohonkan pembatalan suatu nama perusahaan. Hal tersebut di atas di atur pada Article 51 paragraph 1 (Pasal 51 ayat 1) Business Names Registration Act 2011 mengatur: "To avoid doubt, the relief that a court may grant in an action for an infringement of a registered trade mark includes an order that the registration of a business name to an entity must be cancelled." (Terjemahan bebas: "Untuk menghindari keragu-raguan, suatu Putusan Pengadilan dapat diberikan untuk suatu tindakan pelanggaran merek terdaftar, disertai dengan peritnah untuk membatalkan pendaftaran dari suatu nama badan usaha.")

Memperjelas pengaturan di atas, Article 51 paragraph 2 (Pasal 51 ayat 2) Business Names Registration Act 2011 mengatur:

"ASIC must cancel the registration of the business name to the entity if:

(a) a copy of the court's order is lodged with ASIC; and

(b) ASIC is satisfied, within a reasonable period after the order is lodged, that: 
(i) no application for the stay of the order is pending; and

(ii) no appeal of the order is pending; and

Jurnal Yustika

(iii) the order is not stayed; and

(iv) the order has not been overturned on appeal.

(Terjemahan bebas: "ASIC wajib membatalkan pendaftaran suatu nama usaha dari suatu entitas, apabila:

(a) Salinan dari putusan pengadilan yang bersangkutan telah diterima oleh ASIC; dan

(b) ASIC berkeyakinan, bahwa dalam jangka waktu yang wajar setelah putusan tersebut diterima, terjadi:

(i) Tidak ada permohonan penangguhan yang sedang berjalan atas putusan tersebut; dan

Halaman | 112

Passing Off yang

Dilakukan oleh

Pihak yang

Beritikad Tidak Baik

Melalui Pemakaian

Nama Perseroan Terbatas

(ii) Tidak ada banding yang sedang berjalan atas putusan tersebut; dan

(iii) Putusan tersebut tidak ditangguhkan; dan

(iv) Putusan tersebut tidak dibatalkan oleh putusan pada tingkat banding;"

Berdasarkan peraturan-peraturan di atas, dapat dikatakan bahwa pengaturan Business Names Registration Act 2011 memberikan kewenangan bagi lembaga peradilan (yudisial) untuk memutuskan bahwa suatu nama perusahaan dapat dibatalkan karena melanggar suatu hak merek milik orang lain. Hal tersebut menunjukan bahwa telah diatur suatu mekanisme normatif mengenai permasalahan antara fungsi nama merek dan nama perusahaan di negara Australia, sehingga hal ini menunjukan adanya perlindungan serta kepastian hukum bagi seluruh pelaku usaha.

Uraian-uraian dan contoh sebagaimana dijabarkan di atas menunjukan bahwa dibutuhkannya suatu perlindungan hukum dalam bentuk pengaturan yang terintegrasi antara prosedur permohonan nama merek dan prosedur permohonan nama Perseroan Terbatas, sehingga tidak terdapat kemungkinan adanya nama merek yang sama pada pokoknya dengan suatu nama Perseroan Terbatas, yang dapat menimbulkan celah bagi pihak-pihak yang beritikad tidak baik untuk melakukan Passing Off.

\subsubsection{Perlindungan Hukum Pemilik Merek Terdaftar atas Passing Off melalui} Pemakaian Nama Perseroan Terbatas Dalam Perspektif Hukum Kekayaan Intelektual.

Perlindungan hukum yang diberikan terhadap hak ekslusif pemilik merek terdaftar dapat digolongkan menjadi 2 (dua) jenis, yaitu perlindungan hukum preventif dan perlindungan hukum represif.

Perlindungan hukum yang bersifat preventif diberikan dalam bentuk ketentuan normatif mengenai dasar-dasar adanya penolakan permohonan pendaftaran suatu merek, sebagaimana diatur pada Pasal 21 UU Merek. Ketentuan pasal tersebut memberikan perlindungan terhadap pemilik merek dengan cara menolak permohonan pihak lain yang hendak mendaftarkan merek yang memiliki persamaan pada pokoknya 
Jurnal Yustika

Vol. 23 No. 02, Des 2020

Halaman | 113

Passing Off yang

Dilakukan oleh

Pihak yang

Beritikad Tidak

Baik Melalui

Pemakaian Nama

Perseroan Terbatas

Kimham Pentakosta

Elly Hernawati dengan merek yang telah terdaftar terlebih dahulu. Hal ini menunjukkan bahwa pada UU Merek telah terdapat pengaturan yang dapat mencegah adanya suatu pelanggaran terhadap hak eksklusif yang dimiliki oleh pemilik merek.

Pasal 21 ayat (1) huruf b dan c UU Merek secara lebih spesifik mengatur mengenai perlindungan hukum yang bersifat preventif terhadap pemilik Merek Terkenal, dengan cara menolak permohonan pihak lain yang hendak mendaftarkan merek yang memiliki persamaan pada pokoknya atau keseluruhannya dengan suatu Merek Terkenal. Perlindungan terhadap Merek Terkenal tetap dapat diberikan walaupun Merek Terkenal tersebut bukan suatu merek terdaftar, sepanjang Merek Terkenal telah memenuhi kriteria sebagaimana Penjelasan Pasal 21 UU Merek dan Permenkumham Nomor 67 Tahun 2016 yang pada intinya sebagai Merek Terkenal mempunyai reputasi yang diperoleh karena promosi yang gencar dan besar-besaran, adanya investasi di beberapa Negara di dunia dengan disertai bukti pendaftaran merek di beberapa Negara tersebut.

UU Merek juga mengatur mengenai bentuk perlindungan yang bersifat represif, yaitu pengaturan mengenai penanggulangan terhadap suatu pelanggaran merek yang telah terjadi sebagaimana ketentuan Pasal 83 ayat (1) UU Merek sebagai berikut: "Pemilik Merek terdaftar dan/atau penerima Lisensi Merek terdaftar dapat mengajukan gugatan terhadap pihak lain yang secara tanpa hak menggunakan Merek yang mempunyai persamaan pada pokoknya atau keseluruhannya untuk barang dan/atau jasa yang sejenis berupa : a). gugatan ganti rugi dan/atau b). penghentian semua perbuatan yang berkaitan dengan penggunaan merek tersebut.

Perlindungan hukum yang bersifat represif tidak hanya diberikan dalam ranah hukum perdata. Suatu pelanggaran atas merek juga dapat dikenai sanksi pidana sebagaimana ditentukan dalam Pasal 100 ayat (1) dan (2) UU Merek bahwa setiap orang yang dengan tanpa hak menggunakan suatu merek yang memiliki persamaan pada pokoknya atau keseluruhannya dengan merek terdaftar untuk merek barang/jasa sejenis dan diperdagangkan, diancam dengan sanksi penjara dan/atau sanksi denda.

Kedua bentuk perlindungan hukum di atas, baik yang bersifat preventif maupun represif telah memberikan pengaturan yang jelas dalam hal terjadi suatu pelanggaran merek terhadap suatu merek terdaftar dan/atau Merek Terkenal, namun kedua bentuk perlindungan tersebut ternyata hanya meliputi pelanggaran-pelanggaran yang dilakukan melalui tindakan pemakaian atau penggunaan suatu merek.

Kalimat "dengan tanpa hak menggunakan Merek" pada pengaturan Pasal 83 maupun Pasal 100 ayat (1) dan (2) UU Merek tersebut di atas menunjukan bahwa konsep perlindungan hukum yang diberikan oleh UU Merek kepada para pemilik merek terdaftar dan/atau terkenal hanya meliputi tindakan pelanggaran melalui suatu penggunaan atau pemakaian merek, dengan kata lain dapat dikatakan bahwa UU Merek hanya memberikan perlindungan hukum terhadap itikad tidak baik pihak lain yang dilakukan dengan cara penggunaan merek. Pada saat terjadi suatu pelanggaran merek yang dilakukan tanpa melalui penggunaan suatu merek, maka unsur "penggunaan 
merek" yang terdapat pada Pasal 83 maupun Pasal 100 ayat (1) dan (2) UU Merek secara otomatis tidak terpenuhi.

Hal tersebut di atas apabila dikaitkan dengan Passing Off yang dilakukan oleh pihak yang beritikad tidak baik melalui pemakaian nama Perseroan Terbatas, maka kriteria Passing Off tidak masuk dalam definisi terminologi pelanggaran merek sebagaimana diatur pada UU Merek, oleh karena itu dapait dkatakan bahwa tidak terdapat pasal atau pengaturan dalam UU Merek yang dapat memberikan perlindungan bagi pemilik merek terdaftar dan/atau Merek Terkenal yang memakai suatu nama Perseroan Terbatas oleh pihak lain yang beritikad tidak baik

Pemilik merek terdaftar dan/atau Merek Terkenal tidak dapat mengajukan gugatan perdata untuk menuntut ganti rugi sebagaimana diatur pada Pasal 83 UU Merek maupun sebagai suatu tindakan pidana sebagaimana diatur pada Pasal 100 UU Merek, hal tersebut disebabkan karena Passing Off melalui pemakaian nama Perseroan Terbatas bukan merupakan suatu tindakan penggunaan merek, atau dengan kata lain perbuatan tersebut tidak termasuk suatu bentuk pelanggaran merek.

\subsubsection{Perlindungan Hukum Pemilik Merek Terdaftar atas Passing Off melalui Pemakaian Nama Perseroan Terbatas Dalam Perspektif Hukum Persaingan Usaha.}

Pengaturan mengenai hukum persaingan usaha di Indonesia diatur pada UndangUndang Nomor 5 Tahun 1999 Tentang Larangan Praktek Monopoli dan Persaingan Usaha Tidak Sehat (selanjutnya disebut UU Persaingan Usaha).

Pengaturan Pasal 1 huruf f UU Persaingan Usaha memberikan suatu definisi yang sangat luas terhadap pengertian persaingan usaha tidak sehat. Seluruh kegiatan produksi atau pemasaran akan dianggap suatu persaingan usaha tidak sehat, apabila memenuhi unsur-unsur : dilakukan dengan cara tidak jujur; melawan hukum; atau menghambat persaingan usaha.

Penggunaan kata "atau" dalam bahasa penyusunan peraturan perundangundangan mengandung arti bahwa pemenuhan unsur-unsur di atas bersifat alternatif atau dapat dipilih salah satu dari padanya (Maria Farida, 2007). Terkait dengan hal tersebut di atas, apabila suatu tindakan tertentuk telah memenuhi salah satu dari unsur tersebut di atas, maka dapat dikatakan bahwa telah terjadi suatu persaingan usaha tidak sehat.

Berdasarkan uraian tersebut di atas, dalam menentukan bahwa suatu Passing Off sebagai suatu persaingan usaha tidak sehat, maka Passing Off perlu dikaji dengan unsurunsur persaingan usaha tidak sehat sebagaimana disebutkan di atas. Terkait unsur pertama, perbuatan tidak jujur adalah suatu tindakan pengelabuhan yang melanggar etika bisnis, yang dapat dilakukan oleh seorang pelaku usaha dalam bentuk yang beragam, misalnya pengelabuhan mengenai kualitas dan/atau asal-usul barang tertentu (Dio Shafreeza Sunny, 2014). Apabila hal tersebut di atas dikaitkan dengan hakikat fungsi merek dan Perseroan Terbatas adalah penjamin kualitas (Quality Assurance Function), maka suatu Passing Off melalui pemakaian nama Perseroan Terbatas merupakan suatu bentuk upaya untuk mengelabuhi masyarakat konsumen mengenai kualitas dan/atau 
Jurnal Yustika

Vol. 23 No. 02, Des 2020

Halaman | 115

Passing Off yang

Dilakukan oleh

Pihak yang

Beritikad Tidak

Baik Melalui

Pemakaian Nama

Perseroan Terbatas

Kimham Pentakosta

Elly Hernawati asal-usul barang tertentu, sehingga hal tersebut dapat dikatakan sebagai suatu perbuatan tidak jujur. Terkait unsur kedua, bahwa Passing Off merupakan suatu perbuatan yang melanggar hukum, karena dilakukan dengan itikad tidak baik dengan membonceng ketenaran usaha milik pihak lain dan melanggar ketentuan peraturan perundangundangan yang berlaku. Terkait unsur ketiga, suatu Passing Off tentu mengakibatkan kerugian bagi pemilik-pemilik merek terdaftar yang namanya digunakan sebagai nama Perseroan Terbatas, sehingga hal tersebut secara tidak langsung menghambat jalannya suatu persaingan usaha.

Terpenuhinya unsur ketentuan Pasal 1 huruf f UU Persaingan Usaha membuktikan bahwa Passing Off yang dilakukan melalui pemakaian nama Perseroan Terbatas ternyata merupakan suatu tindakan persaingan usaha tidak sehat, sayangnya UU Persaingan usaha tidak memberikan penegasan mengenai sanksi maupun konsekuensi hukum terkait dengan pelanggaran Pasal 1 huruf f UU Persaingan Usaha. Menurut Budi Kagramanto (2015, hal.134), secara sistematik UU Persaingan Usaha hanya mengatur 3 (tiga) bentuk larangan pokok, yaitu perjanjian yang dilarang, kegiatan yang dilarang serta larangan terhadap posisi dominan, dimana ketiganya tidak mengatur atau setidak-tidaknya bersinggungan dengan Passing Off yang dilakukan melalui pemakaian nama Perseroan terbatas.

Sehubungan dengan hal tersebut di atas terdapat suatu celah hukum (loophole) yang dapat dimanfaatkan oleh pelaku usaha yang tidak beritikat baik untuk menciptakan suatu iklim persaingan usaha yang curang dan tidak adil, dengan cara memirip-miripkan nama merek atau nama Perseroan Terbatas dengan milik pihak lain, oleh karenanya diperlukan adanya penyempurnaan pengaturan terkait hukum persaingan usaha di Indonesia,

\subsubsection{Perlindungan Hukum Pemilik Merek Terdaftar atas Passing Off melalui} Pemakaian Nama Perseroan Terbatas Dalam Perspektif Hukum Perdata Umum. Passing Off yang dilakukan melalui pemakaian nama Perseroan Terbatas, merupakan suatu tindakan yang melanggar hak eksklusif yang dimiliki oleh pemilik merek terdaftar dan merupakan suatu tindakan yang bertentangan dengan etika bisnis yang berlaku pada masyarakat, khususnya di kalangan pelaku usaha. Berdasarkan Pasal 1365 Kitab Undang-Undang Hukum Perdata (selanjutnya disebut KUHPerdata), seseorang yang merasa dirugikan oleh karena adanya perbuatan melawan hukum yang dilakukan oleh pihak lain dapat mengajukan gugatan perdata di pengadilan negeri setempat, dengan kata lain, pemilik merek terdaftar atau Merek Terkenal yang merasa dirugikan oleh karena adanya suatu Passing Off yang dilakukan melalui pemakaian nama Perseroan Terbatas dapat mengajukan gugatan terhadap pemilik nama Perseroan Terbatas tersebut.

Unsur-unsur Pasal 1365 KUHPerdata yang terlebih dahulu harus dipenuhi oleh pemilik merek terdaftar atau Merek Terkenal sebelum mengajukan gugatan adalah sebagai berikut: 


\section{1) Unsur perbuatan melawan hukum.}

Perbuatan melawan hukum harus diartikan secara luas sebagai onrechtmatigedaad. Hal tersebut berarti unsur perbuatan melawan hukum tidak hanya terpenuhi apabila seseorang telah melakukan pelanggaran peraturan perundangundangan yang berlaku, melainkan telah terpenuhi apabila seseorang melakukan suatu perbuatan yang melanggar 4 (empat) kriteria yang dapat dikualifikasi sebagai suatu perbuatan melawan hukum menurut Arrest Hoge Raad. Berkaitan dengan hal tersebut, Passing Off melalui pemakaian nama Perseroan Terbatas merupakan suatu tindakan atau perbuatan yang dapat mengurangi hak orang lain, bertentangan dengan kesusilaan (geode zeden), ataupun bertentangan dengan sikap yang baik dalam bermasyarakat, oleh karenanya dapat dikatakan bahwa sesungguhnya suatu Passing Off melalui pemakaian nama Perseroan Terbatas telah memenuhi unsur adanya perbuatan melawan hukum sebagaimana ditentukan dalam pasal 1365 KUHPerdata.

\section{2) Unsur kesalahan.}

Passing Off melalui pemakaian nama Perseroan Terbatas telah memenuhi unsur kesalahan (Schuldelement). Menurut Wirjono Prodjodikoro (2000), unsur kesalahan dapat dibagi menjadi dua jenis, yaitu Kesengajaan (dolus) dan Kealpaan (culpa). Apabila pada saat melakukan permohonan pendaftaran nama Perseroan Terbatas, pemilik nama Perseroan Terbatas tersebut dapat dibuktikan telah mengetahui bahwa nama yang dimohonkan ternyata telah digunakan oleh orang lain sebagai nama merek terdaftar atau Merek Terkenal, maka unsur kesalahan sebagaimana diatur pada Pasal 1365 KUHPerdata dapat dikatakan telah terpenuhi.

\section{3) Unsur kerugian.}

Unsur kerugian dalam Pasal 1365 KUHPerdata telah terpenuhi, karena pemilik merek terdaftar atau Merek Terkenal mengalami kerugian atas Passing Off yang dilakukan melalui pemakaian nama Perseroan Terbatas, baik kerugian materiil maupun kerugian immateriil. Mengenai kerugiaan materiil yang diderita oleh pemilik merek antara lain dalam bentuk berkurangnya laba/keuntungan atas penjualan produk, hilangnya laba/keuntungan yang seharusnya didapat, maupun tidak didapatkannya royalti atau biaya lisensi. Kerugian immateriil dapat terjadi apabila pemakaian nama Perseroan Terbatas yang menggunakan nama merek terdaftar ternyata membawa suatu dampak negatif terhadap reputasi yang dimiliki oleh pemilik merek terdaftar yang bersangkutan (Bently, 2009);

\section{4) Unsur hubungan sebab akibat antara kerugian dan perbuatan.}

Pemilik merek terdaftar atau Merek Terkenal diwajibkan oleh hukum untuk membuktikan bahwa ada kausalitas atau hubungan sebab akibat antara Passing Off melalui pemakaian nama Perseroan Terbatas dengan kerugian yang diderita oleh pemilik merek, baik berupa kerugian materiil maupun immaterial.

Berdasarkan uraian-uraian di atas, maka secara tegas suatu tindakan Passing Off merupakan suatu tindakan perbuatan melawan hukum (onrechtmatige daad) yang
Jurnal Yustika
Vol. 23 No. 02 , Des 2020

Halaman | 116

Passing Off yang

Dilakukan oleh

Pihak yang

Beritikad Tidak Baik

Melalui Pemakaian

Nama Perseroan

Terbatas

Kimham Pentakosta Elly Hernawati 
Jurnal Yustika

Vol. 23 No. 02, Des 2020

Halaman | 117 Passing Off yang Dilakukan oleh Pihak yang Beritikad Tidak Baik Melalui Pemakaian Nama Perseroan Terbatas berikut:

Kimham Pentakosta Elly Hernawati mengakibatkan kerugian, sehingga pihak yang dirugikan, dalam hal ini pemilik merek terdaftar, dapat mengajukan gugatan ke pengadilan. Dengan kata lain, hukum perdata secara umum (Lex generalis) sebenarnya telah memberikan pengaturan yang memungkinkan pemilik merek terdaftar atau Merek Terkenal untuk mempertahankan haknya dan mendapatkan kepastian hukum di pengadilan, walaupun upaya tersebut membutuhkan pembuktian yang cukup berat dan waktu yang cukup panjang di pengadilan.

\section{Kesimpulan}

Berdasarkan uraian-uraian sebagaimana tersebut di atas, dapat ditarik simpulan sebagai

1. Passing off dapat dilakukan melalui pemakaian nama Perseroan Terbatas, sepanjang suatu tindakan tersebut memenuhi 3 (tiga) unsur (Classical Trinity) Passing Off, yaitu unsur reputasi (goodwill), unsur pengelabuhan (mispresentation) dan unsur kerugian (damages);

2. Peraturan perundang-undangan dalam perspektif Hukum Kekayaan Intelektual maupun Hukum Persaingan Usaha sebagai lex specialis belum secara tegas dan khusus mengatur mengenai perlindungan hukum kepada pemilik merek terdaftar yang nama mereknya digunakan sebagai suatu nama Perseroan Terbatas. Apabila pemilik merek terdaftar dirugikan dapat mengajukan gugatan ganti rugi berdasarkan Perbuatan Melawan Hukum dalam KUHPerdata sebagai lex generalis.

Berdasarkan uraian-uraian pada bab-bab sebelumnya, maka dapat disampaikan saran sebagaimana berikut:

1. Perlu adanya suatu pengaturan yang terintegrasi antara prosedur permohonan pendaftaran nama merek dan prosedur permohonan nama perseroan terbatas. Secara konkrit, pemerintah perlu melakukan perubahan pengaturan PP Nomor 43 Tahun 2011, dengan menerapkan adanya pemeriksaan silang (Cross examination) antara nama merek terdaftar dan/atau merek terkenal dengan nama perseroan terbatas yang sedang diajukan;

2. Pemerintah secara mutatis mutandis dapat mengadopsi pengaturan yang diberlakukan di negara Australia, yaitu Business Names Registration Act 2011. Pengaturan Article 51 paragraph 1 (Pasal 51 ayat 1) Business Names Registration Act 2011 pada intinya memberikan hak bagi pemilik merek terdaftar untuk mengajukan permohonan pembatalan nama perusahaan yang telah memakai nama merek terdaftarnya di instansi pengadilan.

\section{Daftar Referensi}

Buku:

Elmer William Hanak, III, 1974, The Quality Assurance Function of Trademarks, 43 FordhamL. 
J. Satrio, 2020, Perseroan Terbatas (Yang Tertutup) Berdasarkan U.U. No. 40 Tahun 2007, Bagian Pertama, Rajawali Press, Depok.

Julius Rizaldi, 2009, Perlindungan Kemasan Produk Merek Terkenal Terhadap Persaingan Curang di Indonesia dikaitkan dengan Undang-undang Merek dan TRIPs-WTO, PT. Alumni, Bandung.

Lionel Bently \& Brad Sherman, 2009, Intellectual Property Law, Oxford University Press Inc., New York, Amerika Serikat.

Maria Farida Indrati S., 2007, Ilmu Perundang-undangan Proses dan Teknik Pembentukannya Jilid 2, Kanisius, Daerah Istimewa Yogyakarta.

Muhammad Djumhana \& Djubaeda, 2003, Hak Milik Intelektual, Sejarah Teori dan Prakteknya di Indonesia, PT Citra Aditya Bakti, Bandung.

Rahmi Jened, 2015, Hukum Merek Trademark Law Dalam Era Global \& Integrasi Ekonomi, Kencana, Surabaya.

-------, 2007, Hak Kekayaan Intelektual Penyalahgunaan Hak Eksklusif, Airlangga University Press, Surabaya.

Wirjono Prodjodikoro, 2000, Perbuatan Melanggar Hukum Dipandang dari Sudut Hukum Perdata, CV Mandar Maju, Bandung.

\section{Artikel Jurnal:}

Agung Sujatmiko, 2010, Prinsip Hukum Penyelesaian Pelanggaran Passing Off Dalam Hukum Merek, Yuridika Vol. 25 No. 1.

Dio Shafreeza Sunny, 2014, Tanggung Gugat Produsen Pemilik Produk yang Melakukan Pemboncengan Reputasi (Passing Off), Universitas Airlangga, Surabaya. 